Article

\title{
Transferring the Cost of Wage Rigidity to Subcontracting Firms: The Case of Korea
}

\author{
Kwangho Woo ${ }^{1}$ and Joonmo Cho ${ }^{2, *}$ \\ 1 Korea Economic Research Institute, Seoul 110-745, Korea; wookh@keri.org \\ 2 School of Economics, Sungkyunkwan University, Seoul 110-745, Korea \\ * Correspondence: trustcho@skku.edu; Tel.: +82-2-760-0422 \\ Academic Editor: Tin-Chih Toly Chen \\ Received: 24 June 2016; Accepted: 19 August 2016; Published: 30 August 2016
}

\begin{abstract}
We select a Korean case with ample subcontracting practices and a rigid wage system. Workplaces with subcontract transactions would have reason to impute the additional wage incremental costs associated with the seniority-based wage system (Hobong in Korea) to subcontractors. Our empirical results identify the cost-transferring mechanism under which the cost of wage rigidity for contractors is transferred to subcontracting firms and aggravates the wage inequality among workers in contracting and subcontracting firms. We analyze the industrial difference in the intensity of this transferring mechanism and probe policy directions considering the improvement of both the subcontracting structure and pay system simultaneously. For the sustainability of firms, they need to reform a seniority-based wage system, an incentive-based wage system or a job-based wage system and the exploited subcontracting structure for creating share value.
\end{abstract}

Keywords: subcontracting practices; rigid wage system; cost-transferring mechanism; wage inequality among firms

\section{Introduction}

In Korea, medium and small-sized companies are subcontracted from large companies in order to manufacture the components of products. There is much controversy concerning the problems regarding the structure of subcontract transactions in Korea. According to the data released from the Small and Medium Business Administration, 43.2 percent of medium and small-sized companies were involved with subcontract transactions, and the degree of dependency of subcontractors on the main contractor is very high (as much as 76.7 percent (the figures came from the "Research report on small and medium sized companies in 2010", and the dependency of subcontractor subcontractors on the main contractor refers to the proportion of the supply contract for the main contractor among the total sale of subcontractors)).

On the other hand, the proportion of workplaces using a seniority-based wage system (HobBong wage system) is very high in Korea. The seniority-based wage system is the wage system that searches for the economic rationality by reconciling wage and productivity throughout one's lifetime on the assumption of life-long employment. Under this wage system, firms would be able to continuously invest in employees, and employees could constantly improve productivity, have a feeling of belonging to the company and design a stable work life. However, the seniority-based wage system causes some discrepancies between labor productivity and wage as years of service increase.

Even though some research regarding the subcontract structure and the wage system has been conducted in a separate way, little research has been developed to investigate the interaction between subcontract structures and wage systems. The necessity of analyzing the interaction between subcontract structures and wage systems could be found in the following. In the case of Korea, it can be said that the subcontract structure is close to the dualistic type among the subcontract types 
suggested by Imrie [1]. The dualistic theory could be applied to the situation where the size of a subcontractor is small, the bargaining power for most of the subcontractors is lower than that of the main contractors and the subcontractor should follow the specific conditions and orders from main contractors. Under this condition, the main contractors are more likely to secure their labor flexibility and shift the additional costs to subcontractors, and subcontractors would be forced to passively deliver according to the terms required by the main contractors [2-4].

A workplace using the seniority-based wage system would incur the additional wage increment by seniority, which would be incurred regardless of performance, as well as costs associated with securing labor flexibility and investment in production [5-7]. Therefore, the profit level of the workplace with that wage system would be decreased due to the additional wage increment, even though its profits would be similar to other firms. It can be judged that the workplace having a seniority-based wage system would be motivated to make an effort to improve efficiency through finding a way to implement either the seniority-based wage system along with the job-based wage system or the competence-based wage system. However, workplaces with subcontract transactions would have cause to impute the additional wage incremental costs associated with the seniority-based wage system to subcontractors rather than to improve the wage system, which would incur complicated issues. If contractors can attribute these costs to subcontractors through the requests of price reduction, they would minimize the burden of wage increases and conflicts with their employees and increase their wage level. Due to these causes, the incentives of main contractors to improve their wage system would be gradually diminished, and the financial difficulties of subcontractors would be enlarged as a result of the price reduction. Worse than this, it may be expected that the wage gap between main contractors and subcontractors would be intensified, the quality of product to be delivered to the main contractors would be deteriorated and the financial difficulties of small and medium-sized companies would be exacerbated.

By analyzing subcontract structures and pay systems, as well as the interaction between them, the main purpose of this study will be to evaluate the very existence of their relationship. This paper attempts to empirically explore how subcontract structures and pay types bring about the wage gap among firms by analyzing the interaction between the subcontract stage, such as main contractor-first level subcontractor-second level subcontractor and pay types, such as the seniority-based wage system, the job-based wage system and the competence-based wage system. It also tries to quantitatively estimate the degree to which these links cause the wage gap by analyzing these relationships by industry. This information could help the basis to make the policy of improving the wage gap tailoring to the characteristics of industry by empirically analyzing the relationships by industry.

This paper proceeds as follows. Section 2 investigates previous literature and the current states in Korea regarding subcontract structures and wage systems. Section 3 examines the model for the empirical analysis and basic statistics of the data for this study. Section 4 investigates subcontract structures, wage systems, as well as the interaction of them on the pay level by empirically analyzing the various models specified in Section 3. Lastly, Section 5 provides conclusions and policy implications.

\section{Previous Literature}

According to previous studies, subcontracts can be divided into three types. The first is the dualistic theory. The dualistic theory is based on the assumption that the main contractor and the subcontractor do not have equal status. Characteristics of this theory include (1) the size of subcontractors is small; (2) most subcontractors have weaker bargaining power than the main contractor in subcontract transactions and (3) subcontractors are forced to follow the specific conditions and orders of the main contractor. Under these conditions, main contractors are more likely to ascribe additional costs related to labor flexibility and production investment to subcontractors and force subcontractors to passively deliver to the main contractors through requested conditions [8]. Besides, under the dualistic theory, this relationship is not improved as time goes by and, thus, produces a vicious circle. This dualistic theory has persuasive power in most Korean subcontract relationships. 
According to domestic studies on subcontracts, the Ministry of Employment and Labor in Korea analyzed wage level by subcontract step and causes of the wage gap by in-depth interviews and reported the following. Among companies who answered questions through interviews, the wage gap between the main contractors and subcontractors is about 70 percent of large companies for first-level subcontractors and about 50-60 percent of large companies for second-level subcontractors. The first cause of the wage gap was reported as the continuous price reduction of the main contractors. These price reduction requests regarding large companies continued on to first-, second- and third-level subcontractors. Especially, problems were getting worse as first-level subcontractors requested too much price reduction for the second-level subcontractors. The second cause is the fact that large companies covered wage increment to prevent union strikes from the price reduction of subcontractors. First-level contractors reported technical support from the main contractors and second-level subcontractors COD (cash on delivery) and the fair-trade monitoring system as resolutions with the most priority.

The dualistic theory delineates the relation between contractors and subcontractors as the master and subordinate. The dualistic theory and the development theory are similar, but the former is for exploitation and the latter for mutual development. The developmental theory suggests that subcontracts have a positive role for larger companies, as well as medium and small-sized companies. In other words, the core of the development theory is that medium and small-sized companies would be modernized and create jobs in the process of implementing subcontracts [9-11]. UNIDO (United Nation Industrial Development Organization) also argued that medium and small-sized companies could access the market of larger companies through subcontracts and have a chance to develop by securing stable resources and technological supports. These arguments also mention that the outsourcing of large companies is one of the methods to focus on core areas rather than to utilize the low wage for the medium and small-sized companies [12-14].

However, opposing opinions state that it is difficult to apply this theory to contemporary situations, since it dichotomizes the modernized large companies, as well as old, medium and small-sized companies [15-17]. Kongmanila and Takahashi [18] analyzed the determinants of subcontracts by analyzing the survey data of 72 textile companies in Laos. According to the results of the analysis using firm performance (ROA; Return On Assets, production) as a dependent variable, $\mathrm{ROA}$ and production were higher in companies with subcontractors than in companies without them. Therefore, the authors concluded that these results could be inferred to coincide with the development theory in that firm performance is improved by subcontract transactions even though the subcontract is with relatively larger companies. Lynch and Jin [19] suggest productivity through knowledge creation and innovation, so the viewpoint of this theory, development theory, has support.

The alternative theory is network theory, which is mostly comprised of medium and small-sized companies. This theory suggests that medium and small-sized companies make a contract in order to consult each other and solve their problems by forming their network [20-22]. This provides an advantage to focus more on their core business by outsourcing peripheral business to others. Rama and Calatrava [23] demonstrated that this relationship has a tremendous effect on the activation of the local economy, as well as the medium and small-sized companies themselves in the analysis of the Spanish electricity industry. Taymaz and Kilicasan [16] analyzed determinant factors of subcontracts in textile and high technology industries by using the 1993-2000 panel data of Turkey. The result differs depending on the type of industry.

\section{Current States of Subcontract Structures and Pay Systems in Korea}

We used the Workplace Panel Survey 2009 (WPS2009) for examining transferring the cost of wage rigidity to subcontracting firms. The WPS is a statistical survey approved by the national government and conducted by the Korea Labor Institute. The population of the WPS2007 includes workplaces across the country with 30 or more employees, and the surveys are conducted with over 18,000 sample 
workplaces to represent workplaces in Korea using stratified sampling. The WPS is the only one that had information about level of subcontract. This is why we selected the WPS data.

Before analyzing the transferring of the cost of wage rigidity to subcontracting firms, we examine the conditions of subcontract structures by firm size. As see the Table 1, on the whole, the proportion of workplaces without subcontracts is most high, being approximately 77 percent, and that of workplaces only using subcontractors is roughly 11 percent. For workplaces only using subcontractors by workplace size, as firm size increases, the proportion of workplaces only using subcontractors is increased to 10.7 percent in workplaces having fewer than 99 employees, 11.2 percent for 100-299 employees and 18.2 percent in workplaces having more than 300 employees. On the other hand, the proportion of workplaces only working as subcontractors is most high being, eight percent compared to the whole sample, 35 percent compared to the sample with subcontract transactions in workplaces having fewer than 99 employees and 16 percent in workplaces with 100-299 employees.

Table 1. The size of companies and subcontract structures (Workplace Panel Survey 2009 (WPS2009)). Unit: number of firms.

\begin{tabular}{|c|c|c|c|c|c|c|}
\hline & & \multicolumn{4}{|c|}{ Type of Subcontract } & \multirow{2}{*}{ Total } \\
\hline & & Type 1 & Type 2 & Type 3 & Type 4 & \\
\hline \multirow{3}{*}{ Firms Size } & $\begin{array}{c}\text { Less than } 100 \\
(\%)\end{array}$ & $\begin{array}{l}1406 \\
(10.7)\end{array}$ & $\begin{array}{c}606 \\
(4.6) \\
\end{array}$ & $\begin{array}{l}1060 \\
(8.0)\end{array}$ & $\begin{array}{l}10,121 \\
(76.7)\end{array}$ & $\begin{array}{l}13,193 \\
(100.0)\end{array}$ \\
\hline & $\begin{array}{c}100-299 \\
(\%)\end{array}$ & $\begin{array}{c}466 \\
(11.2)\end{array}$ & $\begin{array}{l}273 \\
(6.6)\end{array}$ & $\begin{array}{l}137 \\
(3.3)\end{array}$ & $\begin{array}{l}3287 \\
(79.0)\end{array}$ & $\begin{array}{c}4163 \\
(100.0)\end{array}$ \\
\hline & $\begin{array}{c}\text { More than } 300 \\
(\%)\end{array}$ & $\begin{array}{c}219 \\
(18.2)\end{array}$ & $\begin{array}{c}77 \\
(6.4)\end{array}$ & $\begin{array}{c}44 \\
(3.7)\end{array}$ & $\begin{array}{c}863 \\
(71.7)\end{array}$ & $\begin{array}{c}1203 \\
(100.0)\end{array}$ \\
\hline \multicolumn{2}{|c|}{$\begin{array}{c}\text { Total } \\
(\%)\end{array}$} & $\begin{array}{c}2091 \\
(11.3)\end{array}$ & $\begin{array}{c}956 \\
(5.2)\end{array}$ & $\begin{array}{l}1241 \\
(6.7)\end{array}$ & $\begin{array}{c}14,271 \\
(76.9)\end{array}$ & $\begin{array}{l}18,559 \\
(100.0)\end{array}$ \\
\hline
\end{tabular}

Notes: Firm size is classified by the number of employees. Type 1, only using a subcontractor; Type 2, working as subcontractors and using subcontractor; Type 3, only working as a subcontractor; Type 4, non-subcontracting firms.

Table 2 represents the average wage level by firm size and subcontract types. The highest average wage is about 25,320 Won (Korean currency) in workplaces using only subcontractors; that of workplaces using and working as subcontractors is 22,990 Won; that of workplaces only working as subcontractors is 22,560 Won; and that of workplaces without a subcontract is 22,380 Won. Among workplaces with fewer than 99 employees, the highest average wage for workplaces only using subcontractors is 24,170 Won and is 2000 Won higher than that of similar size workplaces (22,170 Won). This means that there exists a big wage gap across different subcontract types. The similar pattern appears in workplaces with 100-299 employees as in workplaces with few than 99 employees. However, the difference between workplaces only using subcontractors and the total average is larger by as much as 3350 Won. The difference increases as it goes to workplaces only working as subcontractors.

In previous research on the wage system, base pay and wage increases are determined by the value of the job in the job-based pay system, knowledge and skills in the competence-based pay system and years of services in the workplaces in the seniority-based pay system (Hobong) [24]. While many macro theory studies on pay system determination factors examined why some companies have specific pay systems, there has been little micro study at the level of the company. 
Table 2. The average wage by workplace size and type of subcontract (WPS2009).

\begin{tabular}{cccc}
\hline Firm Size & Type of Subcontracting & Mean (KRW in Millions) & SD \\
\hline \multirow{4}{*}{ Less than 99 } & Type 1 & 2416.7 & 537.0 \\
& Type 2 & 2212.9 & 346.9 \\
& Type 3 & 2227.6 & 276.4 \\
& Type 4 & 2191.6 & 453.6 \\
& Subtotal & 2217.2 & 451.2 \\
\hline \multirow{3}{*}{$100-299$} & Type 1 & 2674.5 & 493.1 \\
& Type 2 & 2329.3 & 410.7 \\
& Type 3 & 2420.8 & 448.5 \\
& Type 4 & 2287.2 & 578.1 \\
& Subtotal & 2339.9 & 568.3 \\
\hline \multirow{3}{*}{ More than 300 } & Type 1 & 2857.8 & 597.0 \\
& Type 2 & 2860.4 & 382.7 \\
& Type 3 & 2372.0 & 781.7 \\
& Type 4 & 2574.2 & 497.9 \\
& Subtotal & 2637.0 & 539.6 \\
\hline
\end{tabular}

Notes: Type 1, only using a subcontractor; Type 2, working as subcontractors and using a subcontractor; Type 3 , only working as a subcontractor; Type 4, non-subcontracting firms.

Firstly, the job-based pay system assesses the relative contribution of each job for the attainment of firm objectives and pay differentiated according to these criteria [25-27]. It is applied to the production workers and white-collar jobs mainly in the U.S. It appears to be similar to a rational institution in that it determines the wage rate through the relatively objective criteria of a job's relative value and considers market conditions and competition relationships. However, it involves problems, such as the limitation of motivation and individual ability development, as well as burdens of innovation and new technology. Therefore, companies search for various alternative institutes to complement it.

The Japanese pay system is the comprehensive product of the manufacturing-focused economy, the integrative skill formation system and the paternalistic enterprise industrial relations. However, after Japan experienced 'the lost ten years', the dominant direction of pay system improvements has progressed toward the relaxation of seniority in the previous competence-based pay system rather than the transformation into the job-based pay system regarding the U.S. The seniority-based pay system found in most Korean companies is the pay system that searches for the economic rationality by reconciling wage and productivity throughout one's lifetime on the assumption of long-term employment. Under this pay system, firms could continually invest in employees based on the long-term employment relationship, and employees could continuously improve productivity and design a stable work life having a feeling of belongingness to the company. However, the discrepancy between wage and labor productivity would happen at some point, as wage increases by years of service.

According to Table 3, it can be said that, on the whole, the proportion of workplaces with the seniority-based pay system is very high, as the proportion of workplaces using this pay system is 56.8 percent, and that of workplaces combining the seniority-based pay system and other pay systems, such as job-based and competence-based pay systems, is 17.4 percent. Therefore, workplaces incorporating the seniority-based pay system total 74.2 percent. Moreover, a difference by firm size exists, since the frequency of using the seniority-based pay system is higher in workplaces having more than 300 employees and lower in workplaces with fewer than 99 employees. 
Table 3. Pay systems by firm size (WPS2009).

\begin{tabular}{cccc}
\hline & \multicolumn{3}{c}{ Type of Wage Structure } \\
\cline { 2 - 4 } & A & B & C \\
\hline Less than 99 & 7108 & 2320 & 3765 \\
$(\%)$ & $(53.9)$ & $(17.6)$ & $(28.5)$ \\
\hline $99-300$ & 2646 & 669 & 847 \\
$(\%)$ & $(63.6)$ & $(16.1)$ & $(20.4)$ \\
\hline More than 300 & 794 & 249 & 159 \\
$(\%)$ & $(66.1)$ & $(20.7)$ & $(13.2)$ \\
\hline Total & 10,548 & 3238 & 4771 \\
$(\%)$ & $(56.8)$ & $(17.4)$ & $(25.7)$ \\
\hline
\end{tabular}

Notes: A, seniority-based system; B, seniority-based + job-based or skill-based system; C, job-based or skill-based system.

Table 4 represents the average wage of different pay systems by size. The average wage of workplaces having fewer than 99 employees and between 100 and 299 employees is highest in workplaces combining the seniority-based pay system and other pay systems, while the average wage of workplaces with more than 300 employees is highest in workplaces with only the seniority-based pay system.

Table 4. Average wage of different pay systems by firm size (WPS2009).

\begin{tabular}{cccc}
\hline Firm Size & Type of Wage Structure & Mean (KRW in Millions) & SD \\
\hline \multirow{3}{*}{ Less than 99} & A & 2251.5 & 456.6 \\
& B & 2302.7 & 457.5 \\
& C & 2095.6 & 410.6 \\
$100-299$ & Subtotal & 2217.2 & 451.2 \\
\hline \multirow{2}{*}{10} & 2326.7 & 553.6 \\
& A & 2520.9 & 539.9 \\
More than 300 & Cubtotal & 2232.8 & 600.7 \\
& A & 2339.9 & 568.3 \\
\hline & B & 2672.6 & 523.7 \\
& C & 2619.6 & 545.8 \\
& Subtotal & 2487.4 & 582.1 \\
& & 2637.0 & 539.6 \\
\hline
\end{tabular}

Notes: A, seniority-based system; B, seniority-based + job-based or skill-based system; C, job-based or skill-based system.

The study on subcontract structures and pay systems would have the following importance. As can be seen in the previous section, the Korean subcontract structure would be close to the dualistic theory proposed by Imrie [1]. Under its circumstances, the main contractors are more likely to attribute the additional costs of securing labor flexibility and investing on production to subcontractors and force subcontractors to deliver products according to the conditions requested by the main contractors $[2,3]$. Workplaces having transactions with the main contractors incorporating the Hobong pay system would demonstrate differences from those workplaces incorporating the job-based pay system, which pays for the job the individual employee, occupies or the competence-based pay system, which pays for the ability regarding individual employees.

The reason is that workplaces with the seniority-based pay system would incur an additional wage increment, which is not related to performance, by using the seniority-based pay system, as well as the costs associated with securing labor flexibility and investing in production [22,28,29]. Therefore, even if workplaces using the seniority-based pay system would acquire the same profit as workplaces with other pay systems, their real profit would be diminished by the additional wage increment 
through the use of the seniority-based pay system. However, workplaces with subcontract transactions would have an incentive to choose the method of attributing the cost of the additional wage increment associated with the seniority-based pay system to subcontractors rather than improving the pay system, which would give rise to the issues at hand. The main contractors could minimize the burden of wage increase and conflicts with employees and increase their wage level by assigning these costs to subcontractors through requests of price reduction. As a result of this incentive, the incentive for the main contractors to improve the pay system would be gradually diminished, and the difficulty of subcontractors due to price reduction would be progressively enlarged. Like this, the effect on wage might have a serial effect through the interaction between subcontract structures and the seniority-based pay system. Table 5 investigates the average wage by dividing subcontract types and workplaces with and without subcontract transactions. We can observe that the wage level decreases as it goes from workplaces only using subcontractors to subcontractors, and the average wage of workplaces with the seniority-based pay system is higher than workplaces without it. From these statistics, the possibility of the effect of interaction between the subcontract structure and the Hobong pay system on wage can be inferred. Therefore, we will explore whether the subcontract transaction, the seniority-based pay system and the interaction between them influence the wage level after firm size, workplaces characteristics and firm performance.

Table 5. Average wage in firms by subcontracting type and wage-structure (WPS2009).

\begin{tabular}{ccc}
\hline & Seniority-Based Firms & Others Firms \\
\hline \multirow{2}{*}{ Type 1} & 2664.165 & 2413.146 \\
& $(406.909)$ & $(552.958)$ \\
\hline \multirow{2}{*}{ Type 2 } & 2362.898 & 2366.565 \\
& $(406.909)$ & $(377.653)$ \\
\hline \multirow{2}{*}{ Type 3 } & 2316.598 & 2121.704 \\
& $(352.967)$ & $(405.667)$ \\
\hline \multirow{2}{*}{ Type 4 } & 2271.996 & 2194.171 \\
& $(492.890)$ & $(475.165)$ \\
\hline
\end{tabular}

Notes: Unit; KRW in millions; standard deviations are in the parenthesis. Type 1, only using a subcontractor; Type 2, working as subcontractors and using a subcontractor; Type 3, only working as a subcontractor; Type 4, non-subcontracting firms.

\section{Empirical Model and Data Description}

\subsection{Empirical Model}

We utilized various analysis methods and models to analyze the subcontract structure, the pay system and the interaction between them. The models we used are linear regression with the interaction term, propensity score matching (PSM) and regression-based decomposition. We analyze the difference between subcontract firms and non-subcontract firms using the first one. Furthermore, using the PSM method, we check the robustness if the results on linear regression. In addition, the regression-based decomposition method would tell what factor is more impactful on the wage gap, such as subcontract, wage structures and company characteristics for various industries. The basic model is the following formula.

$$
\ln \text { wage }_{i}=\alpha_{i}+\beta_{i} x_{i}+\gamma_{i} s_{i}+\varepsilon_{i}
$$

In this formula, $\ln w a g e_{i}$ refers to the log value of the average wage in each workplace, and $x_{i}$ denotes firm characteristics, such as industry, firm size, operating profit, regular employee ratio, debt ratio, and so on. $s_{i}$ examines the effect of the use of the seniority-based wage system on wage by using the dummy variable for the use of the seniority-based wage system. $\varepsilon_{i}$ is the error term. 
We also investigate the effect on wage by dividing workplaces with and without subcontract transactions. However, there exists a possibility that the difference would be caused by the heterogeneous group difference between workplaces with and without subcontract transactions. Therefore, this study carries out an additional analysis by using the propensity score matching method proposed by Rosenbaum and Rubin [30]. This method is a non-parameter method that was developed to measure the effect of some programs, such as government policy, firm policy and regulations. The main purpose of the matching method is to create similar conditions when a random experiment is impossible. The reason why we use the PSM method is that there is a possibility that the difference of workplace characteristics with and without subcontract transactions, such as firm size and industry, might offset the effect of subcontract transactions and create bias in estimating the pure effect in this study. Accordingly, this study divides the whole sample into two groups depending on the existence of subcontract type and analyzes the pure effect in the same conditions.

In addition, to analyze the interaction effect of the subcontract structure and the pay system, the following additional model is developed and applied to only workplaces with subcontract transactions.

$$
\begin{gathered}
\ln \text { wage }_{i}=\alpha_{i}+\beta_{i} x_{i}+\gamma_{i} s_{i}+\delta_{i} \text { contract }_{i}+\varepsilon_{i} \\
\ln \text { wage }_{i}=\alpha_{i}+\beta_{i} x_{i}+\gamma_{i} s_{i}+\delta_{i} \text { contract }_{i}+\omega_{i} s_{i} \times \text { contract }_{i}+\varepsilon_{i}
\end{gathered}
$$

Here, contract $t_{i}$ implies the dummy variable for contractors, 1st-level subcontractors and 2nd-level subcontractors, respectively, and $s_{i} \times$ contract $_{i}$ means the interaction term between the seniority-based pay system and the subcontract structure.

Lastly, we examine both the proportion and the degree of wage gap caused through the regression-based decomposition analysis by industry. This decomposition method can calculate the effect of independent variables on the dependent variable and indicate how much effect each factor has through the decomposition of variance. Therefore, the results of this analysis could be utilized as a useful tool to help policy decisions on wage inequality and other areas [31].

\subsection{Data Description}

This study empirically analyzes the 2009 WPS (Workplace Panel Survey) data. The WPS is the workplace level data operated by the KLI (Korea Labor Institute), which reports the employment structure, human resource management and industrial relations of Korean companies. Table 6 summarizes the descriptive statistics by dividing workplaces with and without subcontract transactions. The wage of a workplace without subcontracts is higher than that of workplaces with it. The proportion of the Hobong system is higher in workplaces with subcontract transactions.

Table 6. Descriptive statistics.

\begin{tabular}{ccc}
\hline & Subcontracting Firms & Non-Subcontracting \\
\hline Wage (KRW in millions) & 2222.597 & 2373.073 \\
& $(483.345)$ & $(487.616)$ \\
\hline \multirow{2}{*}{ Seniority based system (Hobong) } & 0.356 & 0.341 \\
Union & $(0.479)$ & $(0.474)$ \\
\hline \multirow{2}{*}{ Regular employee ratio } & 0.189 & 0.139 \\
& $(0.392)$ & $(0.346)$ \\
\hline \multirow{2}{*}{ Rate of operating profit } & 0.634 & 0.615 \\
& $(0.218)$ & $(0.201)$ \\
\hline \multirow{2}{*}{ Debt ratio } & 2.568 & 2.682 \\
& $(1.640)$ & $(1.401)$ \\
\hline
\end{tabular}


Table 6. Cont.

\begin{tabular}{ccc}
\hline & Subcontracting Firms & Non-Subcontracting \\
\hline & Industry distribution & \\
\hline Automobile manufacturing & 0.096 & 0.182 \\
\hline Electricity, machinery manufacturing & 0.025 & 0.085 \\
\hline Construction & 0.035 & 0.095 \\
\hline Other services & 0.844 & 0.638 \\
\hline & Employee size distribution & 0.739 \\
\hline Less than 100 & 0.748 & 0.204 \\
\hline 100-299 & 0.191 & 0.030 \\
\hline 300-499 & 0.035 & 0.027 \\
\hline
\end{tabular}

Notes: Standard deviations are in parentheses.

\section{Empirical Results}

According to the estimation results in Table 7, we analyze whole samples and two groups by the existence of subcontracting using the propensity score matching method to inspect whether the Hobong system has a significant impact on workplaces with and without subcontract transactions and the degree of this impact. Through the PSM method, we estimate the pure effect of the Hobong system under the same condition by controlling unique characteristics of a company, such as size and industry. The result shows that the coefficient for the use of the Hobong system variable demonstrates statistical significance at a level of five percent in the sample regarding workplaces with subcontract transactions. On the other hand, the coefficient for the use of the Hobong system is 0.057 in the sample of workplaces without subcontract transactions, which is lower compared to the sample with subcontract transactions. Therefore, there is a possibility that the effect of the inflexible Hobong system is larger in workplaces using these relationships, and as a result, the wage gap would be larger compared to workplaces without the subcontract transactions.

Table 7. The analysis results of the whole sample and by the existence of a subcontract using the propensity score matching (PSM) method.

\begin{tabular}{|c|c|c|c|}
\hline & $\begin{array}{c}\text { Whole Samples } \\
\text { ln Wage }\end{array}$ & $\begin{array}{l}\text { Subcontracting Firms: } \\
\text { ln Wage }\end{array}$ & $\begin{array}{c}\text { Non-Subcontracting Firms: } \\
\text { ln Wage }\end{array}$ \\
\hline Union & $\begin{array}{c}0.027 \\
(0.018)\end{array}$ & $\begin{array}{c}0.033 \\
(0.048)\end{array}$ & $\begin{array}{c}0.024 \\
(0.035)\end{array}$ \\
\hline Rate of operating profit & $\begin{array}{l}0.029^{* * *} \\
(0.004)\end{array}$ & $\begin{array}{l}0.023^{* *} \\
(0.011)\end{array}$ & $\begin{array}{l}0.064^{* * *} \\
(0.008)\end{array}$ \\
\hline Debt ratio & $\begin{array}{l}-0.013^{* *} \\
(0.005)\end{array}$ & $\begin{array}{l}-0.025^{*} \\
(0.013)\end{array}$ & $\begin{array}{l}-0.016 \\
(0.010)\end{array}$ \\
\hline Hobong & $\begin{array}{l}0.036^{* * *} \\
(0.013)\end{array}$ & $\begin{array}{l}0.094^{* * *} \\
(0.035)\end{array}$ & $\begin{array}{l}0.057^{* *} \\
(0.027)\end{array}$ \\
\hline Industry dummy & Yes & Yes & Yes \\
\hline Employee size & Yes & Yes & Yes \\
\hline Constant & $\begin{array}{l}7.598^{* * *} \\
(0.038)\end{array}$ & $\begin{array}{l}7.727^{* * *} \\
(0.112)\end{array}$ & $\begin{array}{l}7.458^{* * *} \\
(0.075)\end{array}$ \\
\hline Adj. R-squared & 0.143 & 0.164 & 0.275 \\
\hline Observations & 997 & 182 & 183 \\
\hline
\end{tabular}

Notes: Heteroscedasticity-consistent standard errors are in parentheses. Controlled regular employee ration; the reference industry is automobile manufacturing; and employee size is less than 100 . * Significant at the $10 \%$ level; ** significant at the $5 \%$ level; *** significant at the $1 \%$ level. 
Table 8 shows the result of analysis on the interaction of the Hobong system and subcontract structure for the sample with subcontract transactions by using the interaction-term between the Hobong system and the subcontract structure. First, Model 1 analyzes by adding each subcontract type as a variable. The coefficient of the Hobong system is 0.056 and shows statistical significance at the five percent level. The variable of the subcontract type does not have a statistically-significant effect on the wage. However, the wage of the main contractors and the first-level subcontractors with the Hobong system is higher compared to the third-level subcontractors when it is analyzed through the interaction term. Especially, the wage regarding the main contractors is about 15.4 percent higher than that of the third-level subcontractors and demonstrates a very high statistical significance at the one percent level. The wage of first-level subcontractors is approximately nine percent higher than that of the third-level subcontractors, even though it is lower than the main contractors in terms of the size of the coefficient and the significance level. Furthermore, the interaction term between the Hobong system and the second-level subcontractors is not statistically significant.

Table 8. Results of the analysis.

\begin{tabular}{ccc}
\hline & Model 1: ln Wage & Model 2: ln Wage \\
\hline Hobong & $0.056^{* *}$ & -0.007 \\
& $(0.026)$ & $(0.030)$ \\
\hline Type of Subcontract & \\
\hline Type 1 & 0.009 & $0.141^{* *}$ \\
& $(0.047)$ & $(0.059)$ \\
\hline Type 2 & 0.057 & $0.143^{* *}$ \\
& $(0.048)$ & $(0.057)$ \\
\hline Type 3 & 0.059 & $0.150 * *$ \\
& $(0.047)$ & $(0.066)$ \\
\hline Hobong $\times$ Type 1 & & $0.154^{* * *}$ \\
& & $(0.046)$ \\
\hline Hobong $\times$ Type 2 & & $0.090^{*}$ \\
\hline \multirow{2}{*}{ Hobong $\times$ Type 3 } & & $(0.047)$ \\
\hline Industry dummy & Yes & 0.087 \\
Employee size & Yes & $(0.059)$ \\
\hline Constant & $7.502 * * *$ & Yes \\
\hline Observations & $(0.086)$ & Yes \\
\hline Adj. R-squared & 194 & $(0.088)$ \\
\hline
\end{tabular}

Notes: Heteroscedasticity-consistent standard errors are in parentheses. We controlled the regular employee ratio, union, rate of operating profit and debt ratio. The reference industry is automobile manufacturing; the employee size is less than 100; and the type of subcontract is Type 4 . Type 1, only using a subcontractor; Type 2, first working as subcontractors and using a subcontractor; Type 3 , second working as subcontractors and using a subcontractor; Type 4 , only working as a subcontractor. * Significant at the $10 \%$ level; ** significant at the $5 \%$ level; ${ }^{* * *}$ Significant at the $1 \%$ level.

The main contractors with the Hobong system differ from workplaces with other pay systems. The reason is that workplaces using the Hobong system incur the additional wage increment, which would occur without the direct association with performance level by using the seniority-based wage system, as well as the costs associated with securing labor flexibility and production investment. The main contractor can minimize the burden of the additional wage increment and conflicts with employees by crediting costs to subcontractors by means of the price reduction request. It can be expected that the workplaces with the Hobong system, which has a gap with performance and the 
conditions of the company, have additional cost, and the incentive to attribute costs to subcontractors would be higher compared to workplaces without the Hobong system. There is a high probability that first-level subcontractors have a better bargaining position compared to second-level subcontractors and an incentive to charge second-level subcontractors. This incentive is more likely to be higher for the workplaces with the Hobong system. It can be inferred that the bargaining power of second-level subcontractors over third-level subcontractors is not that much stronger compared to that of the main contractors and first-level subcontractors, as well as first-level subcontractors and second-level subcontractors by the fact that the interaction of second-level subcontractors is statistically insignificant.

Table 9 compares and analyzes workplaces with and without the Hobong system for the sample of workplaces with subcontract transactions. The analysis results indicate that the wage of first-level subcontractors is approximately 6.2 percent and that of second-level subcontractors is about 7.3 percent lower compared to that of the main contractors in the sample regarding workplaces with the Hobong system. On the contrary, workplaces without the Hobong system show differences with workplaces with the Hobong system in that the coefficients of the first- and second-level contractees do not demonstrate statistical significance.

Table 9. The comparison between workplaces with and without the Hobong system in the subcontract sample.

\begin{tabular}{|c|c|c|}
\hline & $\begin{array}{l}\text { Subcontracting and Hobong: } \\
\text { ln Wage }\end{array}$ & $\begin{array}{l}\text { Subcontracting and Non Hobong: } \\
\text { ln Wage }\end{array}$ \\
\hline Regular employee ratio & $\begin{array}{l}0.301^{* * *} \\
(0.074)\end{array}$ & $\begin{array}{c}0.116 \\
(0.087)\end{array}$ \\
\hline Union & $\begin{array}{l}0.119 * * * \\
(0.035)\end{array}$ & $\begin{array}{l}-0.098 \\
(0.061)\end{array}$ \\
\hline Rate of operating profit & $\begin{array}{l}0.019 * \\
(0.010)\end{array}$ & $\begin{array}{l}0.027 * * \\
(0.012)\end{array}$ \\
\hline Debt ratio & $\begin{array}{l}-0.042 * * * \\
(0.012)\end{array}$ & $\begin{array}{l}-0.002 \\
(0.014)\end{array}$ \\
\hline \multicolumn{3}{|c|}{ Type of Subcontract } \\
\hline Type I & $\begin{array}{l}-0.062 * \\
(0.037)\end{array}$ & $\begin{array}{c}0.011 \\
(0.037)\end{array}$ \\
\hline Type II & $\begin{array}{l}-0.073^{* *} \\
(0.034)\end{array}$ & $\begin{array}{l}-0.061 \\
(0.042)\end{array}$ \\
\hline Industry dummy & Yes & Yes \\
\hline Employee size & Yes & Yes \\
\hline Constant & $\begin{array}{l}7.651^{* * *} \\
(0.084)\end{array}$ & $\begin{array}{l}7.581 * * * \\
(0.103)\end{array}$ \\
\hline Observations & 149 & 169 \\
\hline Adj. R-squared & 0.398 & 0.091 \\
\hline
\end{tabular}

Notes: Heteroscedasticity-consistent standard errors are in parentheses. The reference industry is automobile manufacturing; the employee size is less than 100; and the type of subcontract is Type III. Type I, only using a subcontractor; Type II, working as subcontractors and using a subcontractor; Type III, only working as a subcontractor. * Significant at the $10 \%$ level; ${ }^{* *}$ significant at the $5 \%$ level; ${ }^{* * *}$ significant at the $1 \%$ level.

Figure 1 indicates the proportion of the factor that causes the industry wage gap using the regression-based decomposition. To summarize these results, it can be said that the wage gap caused by the pay system is about 10 percent when the total wage gap in all industries is 100 percent. Furthermore, in the analysis by industry, the proportion explained by firm characteristics is larger in the electricity industry. The proportion explained by the wage system and subcontract structure is about 16 percent and greater than that of the operating profit (about 12.2 percent). Furthermore, 
the proportion explained by the wage system and subcontract structure is about 19.9 percent in the auto industry and greater than those in other industries.

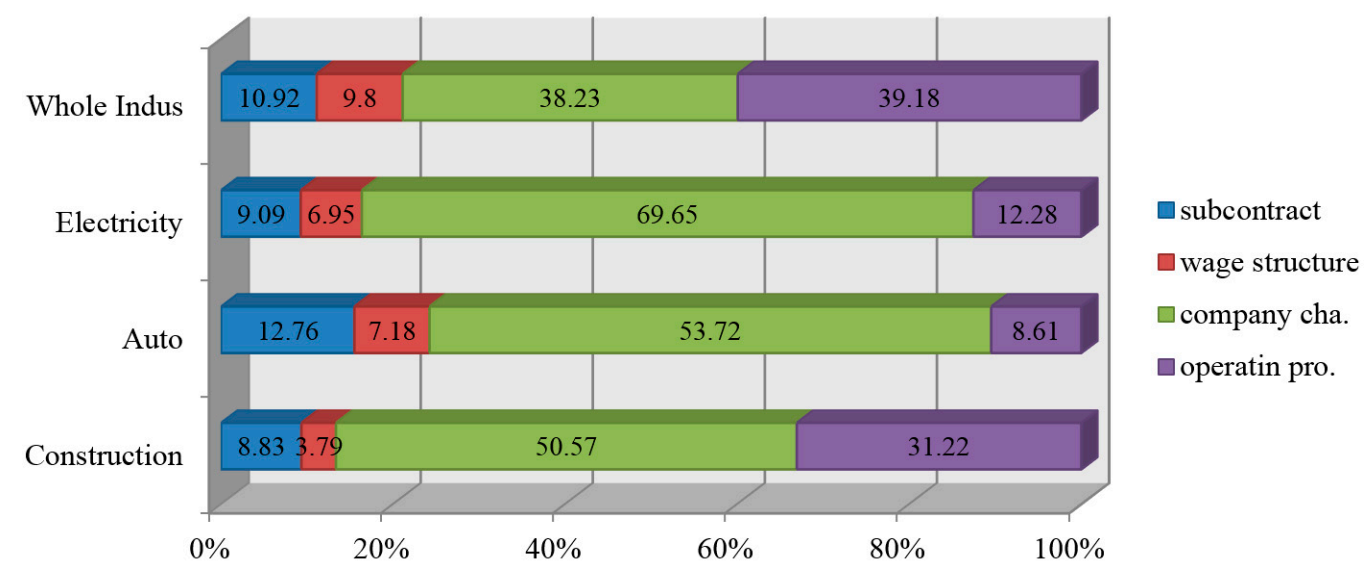

Figure 1. Result of regression-based decomposition.

Moreover, it can be interpreted that the wage gap caused by the pay system and subcontract structure is larger in the auto industry. Previous empirical studies estimated that the ripple effect of employment is larger in the auto industry. However, it is well known that the rigidity of the pay system like the Hobong system and subcontract transactions has been practically fixed in the Korean auto industry. This suggests that, even though, the interaction between pay systems and subcontracts could create some employment in the auto industry through a broad ripple effect. In the construction industry, the proportion explained by pay systems and subcontract transactions is approximately 12.6 percent and lower compared to other industries. These results show that the effect of pay systems and the types of subcontract transactions on wage gap differs depending on industry. In this case, the policy that can consider the improvement of subcontract structures and pay systems simultaneously would be more effective. In addition, policy making decisions considering industry characteristics based on empirical analysis are needed because there exist differences in the causes and the degree to which the wage gap occurs in industries, such as auto, machine and equipment, as well as construction [32].

\section{Discussion of the Findings}

Results of this study can be summarized as follows. The wage level of workplaces with the Hobong pay system was higher than workplaces with other pay systems, and the interaction between the subcontract step and the Hobong pay system only for workplaces with subcontract transactions indicated that the wage incremental differences were getting bigger and statistically significant with the order of the main contractor, the first-level subcontractor and the second-level subcontractor. This result can be interpreted as follows. The reason for the difference between main contractors with and without the Hobong pay system is that workplaces with the seniority-based pay system incurred the additional wage increment, which has been incurred without the direct association with performance by using the seniority-based pay system, as well as costs related to labor flexibility and the production investment. Therefore, the actual profit of workplaces with the seniority-based pay system would be less than other workplaces with different pay systems considering the additional wage increment with the seniority-based pay system, even though the nominal profit level is same. Thus, these workplaces would have an incentive to improve the efficiency in order to solve these problems.

However, workplaces with subcontract transactions would have an incentive to attribute the additional wage increment caused by the use of the seniority-based pay system to subcontractors rather than pay system improvements, which would cause complicated problems. The main contractors could increase the wage level, as well as minimize the burden of the additional wage increment and the possibility of conflicts with labor unions by assigning these costs to subcontractors through price 
reduction requests. As a result, the incentive of main contractors to improve their pay system would be continually diminished, and the difficulty for subcontractors by price reduction would be gradually enlarged. In addition, this study empirically analyzed the existence of the incentive that first-level contractors would attribute costs credited from the main contractors to second-level contractors in order to offset these costs if first-level contractors use the seniority-based pay system. If these relationships were established and continued for a while, it can be expected that the wage gap would be intensified, the product quality to be delivered to the main contractors would be deteriorated and financial problems regarding medium and small-sized companies would be deepened. The necessity for considering the pay system and subcontract structure together provides greater clarity with regards to these links. Since previous studies only analyzed pay systems and subcontract transactions separately, this analysis would be a new approach in that it processes the information more deeply as it explores the interaction effect between them.

In addition, it explored the degree to which pay systems and subcontract transactions cause wage gaps by industry through the regression-based decomposition method. According to the results, the degree to which pay systems and subcontract transactions cause wage gaps is highest in the auto industry. Previous empirical studies reported that the auto industry had the largest ripple effect on employment. However, it is also well known that the inflexibility of pay systems like the Hobong system and subcontract transactions was fixed within the Korean auto industry. This implies that even though the interaction between wage and subcontracts in the auto industry could create employment through broad ripple effects, it also could create wage gaps in the labor market or, further, labor market structuration at the same time. These results imply that the externality of wage rigidity among firms exists through the cost transferring mechanism.

\section{Recommendations}

The cost transferring mechanism is created through the interaction between subcontracting and wage rigidity, aggravating the inequality of wage and profit among workers in both large contracting and small subcontracting firms. Under these circumstances, the institutions for fair-trade alone may not be enough to tackle the aggravation of inequality over various firm sizes. In this case, policies considering the improvement of subcontract structures and pay systems simultaneously would be more effective. In addition, policy making decisions considering industry characteristics based on empirical analysis are needed because there exist differences in the causes and the degree to which the wage gap occurs in industries, such as auto, machine and equipment, as well as construction. These results suggest that firms with the seniority-based wage system change the system to incentive-based wage system or job-based wage system. Furthermore, they reform the exploited subcontracting structure to creating the share value structure for value chain development. The reforms would be a win-win strategy among subcontractors.

\section{Conclusions}

This study examined the causes of the wage gap, which have been mentioned as problems within Korean society since the foreign exchange crisis, through subcontract structures, wage systems and the interaction between them. As far as the knowledge of the authors is concerned, little research has been done that analyzed these two themes at the same time by combining them. Even though some research has been processed to explore subcontract structures and pay system improvement, efforts and research to investigate the interaction between them have been very weak. Recently, the Korea government and firms' CEOs keep trying to reform the labor market for flexibility. The wage structure reform is one of the important issues, and the system needs to be changed to job-based, performance-based or a hybrid type as soon as possible for the sustainability of Korean firms. Furthermore, the data we used in this paper did not included the information about the main contractor and sub-contractees. For future research, the information of these relations would provide more detail and interesting results for leaders. 
Author Contributions: Kwangho Woo developed the methodology, managed and analysis data. Joonmo Cho gave the original idea, developed the study conception and design, and writing of the manuscript.

Conflicts of Interest: The authors declare no conflict of interest.

\section{References}

1. Imrie, R.F. Work decentralization form Large to small firms: A preliminary analysis of Subcontracting. Environ. Plann. 1986, 18, 949-965. [CrossRef]

2. Holmes, J. The Organization and Locational Structure of Production Subcontracting in Scott; Allen \& Unwin: Boston, MA, USA, 1986; pp. 80-106.

3. Watanabe, S. Subcontracting, Industrialisation and Employment Creation. Int. Labour Rev. 1971, 104, 51-76.

4. Perrow, C. The Short and Glorious History of Organizational Theory. Organ. Dyn. 1973, 2, 2-15. [CrossRef]

5. Cho, J. Human resource management, corporate governance structure and corporate performance in Korea: A comparative analysis of Japan, US and Korea. Jpn. World Econ. 2005, 17, 417-430. [CrossRef]

6. Rhee, H.; Woo, K.; Cho, J. Identifying the Winners under the Age Discrimination Prohibition Legislation in Korea: Policy Remedy for Redistribution. J. Asia Pac. Eng. 2013, 19, 186-201. [CrossRef]

7. Cho, J.; Lee, J.; Kwon, T. Gender exclusion in social security protection: Evidence from South Korea. Asian Pac. Econ. Lit. 2013, 27, 62-78. [CrossRef]

8. Alvesson, M.; Lindkvist, L. Transaction Costs, Clans and Corporate Culture. J. Manag. Stud. 1993, 30, 427-452. [CrossRef]

9. Cho, J.; Cho, D. How do Labor Unions Influence the Gender Earnings Gap? A Comparative Study of the US and South Korea. Fem. Econ. 2011, 17, 133-157. [CrossRef]

10. Wesley, M. Employer Size and Wages. Rev. Econ. Stat. 1982, 64, 495-501.

11. Seth, A.; Thomas, H. Theories of the Firm: Implications for Strategy Research. J. Manag. Stud. 1994, 31, 165-192. [CrossRef]

12. Cho, J.; Kwon, T.; Ahn, J. Half success, half failure in South Korean Affirmative Action: An empirical evaluation on corporate progress. Women Stud. Int. Forum. 2010, 33, 264-273. [CrossRef]

13. Diaz-Mora, C.; Triguero-Cano, A. Why do some firms contract out production? Evidence from firm-level panel data. Appl. Econ. 2012, 44, 1631-1644. [CrossRef]

14. Ott, U.F. The Art and Economics of International Negotiations: Haggling Meets Hurrying and Hanging on in Buyer-seller Negotiations. J. Innov. Knowl. 2016, 1, 51-61. [CrossRef]

15. Cho, J.; Linn, S.C.; Nakibullah, A. Tax evasion with psychic costs and penalty renegotiation. South. Econ. J. 1996, 63, 172-190. [CrossRef]

16. Taymaz, E.; Yilmaz, K. Determinants of Subcontracting and Regional Development: An Empirical Study on Turkish Textile and Engineering Industries. Reg. Stud. 2005, 39, 633-645. [CrossRef]

17. Williamson, O.E. Strategizing, Economizing, and Economic Organization. Strateg. Manag. J. 1991, $12,75-94$. [CrossRef]

18. Xayphone, K.; Takahashi, Y. Determinants of Subcontracting and Firm Performance in Lao PDR: Evidence from a Garment Industry Cluster. Asia Pac. Manag. Rev. 2010, 15, 97-112.

19. Lynch, R.; Jin, Z. Exploring the Institutional Perspective on International Business Expansion: Towards a More Detailed Conceptual Framework. J. Innov. Knowl. 2016, 1, 4-11. [CrossRef]

20. United Nations Industrial Development Organization. Subcontracting for Modernizing Economies; United Nations: New York, NY, USA, 1974.

21. United Nations Conference on Trade and Development. Technological Dynamism in Industrial Districts: An Alternative Approach to Industrialization in Developing Countries; United Nations: New York, NY, USA, 1994.

22. Zajac, E.J.; Olsen, C.P. From Transaction Cost to Transaction Value Analysis: Implications for the Study of Interorganizational Strategies. J. Manag. Stud. 1993, 30, 131-145. [CrossRef]

23. Rama, R.; Calatrava, A. The advantages of clustering: The case of Spanish electronics subcontractors through spatial clustering. Int. J. Technol. Manag. 2002, 24, 764-791. [CrossRef]

24. George, T.M.; Jerry, M.N. Compensation, 8th ed.; McGraw-Hill: New York, NY, USA, 2006.

25. Cho, J.; Kim, G.; Kwon, T. Employment problems with irregular workers in Korea: A critical approach to government policy. Pac. Aff. 2008, 81, 407-426. [CrossRef] 
26. Ash, R.A.; Levine, E.L.; Sistrunk, F. The role of jobs and job-based methods in personnel and human resources management. Res. Pers. Hum. Resour. Manag. 1983, 1, 45-84.

27. Raymond, A.N.; Hollenbeck, J.R.; Gerhart, B.; Wright, P.M. Human Resource Management: Gaining a Competitive Advantage, 5th ed.; McGraw-Hill: New York, NY, USA, 2006.

28. Cho, J.; Kwon, T. Affirmative Action and Corporate Compliance in South Korea. Fem. Econ. 2010, 16, 111-139. [CrossRef]

29. Cho, J.; Lim, C.; Lee, J. Gender and Job Turnover in Dual Labor Market: A South Korean Perspective. Asian J. Women's Stud. 2010, 16, 91-124. [CrossRef]

30. Rosenbaum, P.R.; Rubin, D.B. The Central Role of the Propensity Score in Observational Studies for Causal Effects. Biometrika 1983, 70, 41-55. [CrossRef]

31. Gary, S.F. Accounting for Income Inequality and its change: A new method, with Application to the Distribution of Earnings in the United States. Res. Labor E 2003, 22, 1-39.

32. Rumelt, R.P. How Much Does Industry Matter? Strateg. Manag. J. 1991, 12, 167-185. [CrossRef]

(C) 2016 by the authors; licensee MDPI, Basel, Switzerland. This article is an open access article distributed under the terms and conditions of the Creative Commons Attribution (CC-BY) license (http:/ / creativecommons.org/licenses/by/4.0/). 